УДК 373. 013: 373. 091. 33

DOI: $10.35619 /$ iiu.v1i11.258

Петренко Оксана

доктор педагогічних наук, професор,

завідувачка кафедри теорії і методики виховання

Рівненського державного гуманітарного університету,

м. Рівне, Україна

ORCID: 0000-0001-6906-3542

e-mail: o.b.petrenko@gmail.com

\title{
АКТИВНІ Й ІНТЕРАКТИВНІ МЕТОДИ ПОЛІКУЛЬТУРНОГО ВИХОВАННЯ УЧНІВ РІЗНИХ ВІКОВИХ ГРУП
}

\begin{abstract}
Анотація. Полікультурне виховання розглядається як процес цілеспрямованої соціалізації учнів, що передбачає оволодіння системою національних i загальнокультурних цінностей, комунікативних та загальнокультурних емпатійних умінь, що дають учням можливість здійснювати міжкультурну взаємодію i виявляти розуміння інших культур, а також толерантність щодо їх носіїв.
\end{abstract}

Обгрунтовано доцільність використання педагогами у процесі полікультурного виховання активних й інтерактивних методів, які сприяють ефективній взаємодії в класі з представниками різних культур. Схарактеризовано окремі активні й інтерактивні методи полікультурного виховання відповідно до вікових груп учнів.

3'ясовано, що найбільш ефективними методами організації полікультурного виховання у початковій школі $є$ ті, які побудовані на інтеракціях, іграх, формують комунікативні навички, як-то: бесіди, діалоги/обговорення, руханки, рольові ігри/інсценування, аналіз історій, малювання з обговоренням, переконування і т. п.

Найбільш ефективними активними й інтерактивними методами полікультурного виховання з підлітками визначено діалог, дискусію, роботу в парах і групах, мозковий штурм, рольові ігри, контент-аналіз текстів та інших джерел культурної інформації, інтерв'ювання, опитування, метод моделювання конкретних ситуацій, метод кейсів, «криголами», обговорення в колі, виготовлення флаєрів, континуум, оцінку й самооцінку й т. п.

Найбільш ефективними активними й інтерактивними методами полікультурного виховання старшокласників є: дебати, метод проєктів, кооперативне навчання, складання культурологічної автобіографії, рольові та ділові ігри, проведення «круглих столів», етнографічні дослідження, кроскультурні моделювання й т. ін.

Доведено, що використання активних й інтерактивних методів у полікультурному вихованні дає змогу досягти поставлених завдань і сприяє особистісному зростанню як учнів, так і педагогів.

Ключові слова: полікультурне виховання, активні й інтерактивні методи полікультурного виховання, учні, вікові групи, толерантість.

Постановка проблеми. Інтенсивні цивілізаційні процеси, які характерні для сучасного світу, актуалізують проблему міжкультурної взаємодії представників різних етносів як однієї з важливих умов сталого поступу людської цивілізації. Україна як демократична європейська країна активно долучається до цих процесів. Культурне розмаїття українського суспільства характерне традиціями взаємодії етносів і національних культур, серед яких має комфортно почуватися підростаюча

(C) Петренко О., 2020 
особистість. В умовах створення полікультурного демократичного суспільства, економічної, культурної та освітньої інтеграції України в європейське і світове співтовариство особливої актуальності набуває проблема виховання нового покоління, готового до ефективної міжкультурної взаємодії в нових історичних реаліях, стійкого до проявів расизму, ксенофобії, гомофобії і нетерпимості до людських відмінностей. 3 огляду на це перед системою вітчизняної освіти актуалізується потреба забезпечення комфортного гармонійного співіснування представників різних культур у закладах освіти, налагодження їх ефективної взаємодії в полікультурному середовищі, забезпечення системи полікультурного виховання учнів різних вікових груп ефективними методами, насамперед активними й інтерактивними.

Метою статті $\epsilon$ аналіз і характеристика активних й інтерактивних методів полікультурного виховання учнів різних вікових груп у сучасних закладах освіти.

Аналіз останніх досліджень 3 проблеми. Проблему полікультурного виховання в системі освіти останнім часом досліджували В. Бойченко (2006), О. Гурин, П. Кендзьор (2016), О. Свиридюк (2015), А. Солодка (2005), Ю. Сорока, Л. Чумак та ін.

Засадничі положення використання інновацій у системі вітчизняного виховання схарактеризовані О. Петренко (2015); використання активних й інтерактивних методів і технологій у вітчизняній освіті вивчали І. Дичківська (2004), М. Кларін (2000), О. Комар, А. Панфілова (2009), О. Пометун (2004), Л. Пироженко та ін.

Аналіз праць зазначених вчених дає підстави для висновку про те, що більшість 3 них акцентує увагу на з'ясуванні сутності полікультурного виховання та векторів його реалізації в освіті, на визначенні змісту, форм, методів його здійснення та на системі професійної підготовки майбутніх учителів до роботи в полікультурному середовищі; на специфіці застосування інновацій, активних й інтерактивних технологій у системі освіти й виховання.

При цьому недослідженою залишається специфіка застосування активних й інтерактивних форм і методів у полікультурному вихованні особистості в онтогенезі.

Виклад основного матеріалу дослідження. Під полікультурним вихованням в закладах освіти більшість дослідників (В. Бойченко, П. Кендзьор, А. Солодка, О. Свиридюк та ін.) розуміють інтерактивний процес, який забезпечує повноцінний розвиток потенційних і критичних здібностей учнів незалежно від відмінностей, що грунтуються на расовій, етнічній, гендерній i класовій стратифікації суспільства, та передбачає глибоке усвідомлення ними поглядів, умінь і навичок, які є необхідними для життя в плюралістичному суспільстві (Свиридюк, 2015).

Нам імпонує тлумачення поняття «полікультурного виховання» Н. Миропольською як процесу цілеспрямованої соціалізації учнів, що передбачає оволодіння системою національних i загальнокультурних цінностей, комунікативних та загальнокультурних емпатійних умінь, що дають школярам можливість здійснювати міжкультурну взаємодію і виявляти розуміння інших культур, а також толерантність щодо її носіїв (Кендзьор, 2016, с. 82).

Відповідно, метою полікультурного виховання $\epsilon$ особистість, здатна повноцінно реалізувати свої можливості та досягнути високого рівня розвитку, яка має достатній рівень знань, умінь і стратегій підтримки міжособистісних i міжгрупових відносин, необхідних для функціонування в плюралістичному суспільстві; яка здатна позитивно ставитись до членів інших етнокультурних груп. 
Іншими словами, метою полікультурного виховання $є$ особистість з високим рівнем толерантності, яка готова до взаємодії, до активної солідарності, вміє проявляти розуміння, емпатію, повагу до людей іншої національності, інтерес і визнання їх особливостей в умовах багатонаціонального та поліконфесійного суспільства.

Досягненню цієї мети у полікультурному середовищі закладу освіти сприяє використання низки методів, форм і засобів, доцільність яких визначається політичною й соціокультурною ситуацією, типом закладу освіти, віковими особливостями учнів.

У здійсненні полікультурного виховання учнів, як правило, використовують різноманітні організаційні форми, серед яких масові: свята, загальношкільні збори, суботники, тематичні тижні, фестивалі, олімпіади, виставки та ін.; групові: уроки, лекції, гуртки, клуби, класні години, екскурсії, ігри-подорожі, творчі майстерні, дослідницькі лабораторії та ін.; індивідуальні: громадські доручення (черговий, санітар, журналіст та ін.), дослідження в бібліотеці, написання листів, учнівські проєкти або дослідження; індивідуальні завдання, індивідуальна підготовка і участь у конкурсах, вікторинах та ін.

Сучасними вихователями широко застосовуються як традиційні (пасивні) методи, так і нетрадиційні методи, зокрема активні й інтерактивні.

Активні й інтерактивні методи виховання - це насамперед нові методи, за допомогою яких здійснюється переведення особистості учня в позицію активного суб'єкта освітньо-виховного процесу.

Сутність активних методів полягає у тому, що освітньо-виховний процес відбувається за умови постійної, активної взаємодії всіх учнів. Це грунтується на співпраці, взаємодії: вчитель - учень. Під час такого спілкування учні вчаться бути демократичними, спілкуватися 3 іншими людьми, критично мислити, приймати обгрунтовані рішення. При цьому вчитель залишається центральною частиною освітньо-виховного процесу, головним експертом.

На відміну від активних методів, інтерактивні методи орієнтовані на ширшу взаємодію учнів не тільки з учителем, а й між собою на домінування їх активності в освітньому процесі. Роль учителя зводиться до скерування діяльності учнів на досягнення певних цілей, а саме: створення таких умов виховання, за яких кожен суб' єкт відчує свою успішність, цінність.

Обираючи той чи інший метод виховання, педагогам у процесі полікультурного виховання доцільно використовувати не лише традиційні, а й активні й інтерактивні методи виховання, які сприяють продуктивній i ефективній педагогічній взаємодії у класі, де навчаються учні різних національностей, представники різних культур.

Схарактеризуємо окремі активні й інтерактивні методи полікультурного виховання відповідно до вікових категорій учнів, які, на нашу думку, є досить ефективними, але ще не так часто використовуються у сучасних закладах освіти, як повинні були б.

У початковій школі активні й інтерактивні методи полікультурного виховання мають застосовуватись із врахуванням особливостей розвитку дітей молодшого шкільного віку, як-то: прагнення до наслідування поведінки дорослих, передусім членів референтної групи; поступове формування алгоритмів взаємодії в групі тощо. Розвиток у дітей молодшого шкільного віку навиків міжкультурної комунікації виховує в них такі якості, як особиста гідність, відкритість, привітність, емпатія, а також готовність до спілкування. 
3 дітьми молодшого шкільного віку ефективними є такі активні й інтерактивні методи полікультурного виховання, які цікаві дитині й тісно пов'язані 3 iї безпосереднім оточенням.

У початковій школі молодший школяр через пізнання різноманітних культур збагачується знаннями, що сприяє кращому усвідомленню власної культурної ідентичності та природного акцептування й інтеграції в інші культури. Найбільш ефективними методами організації полікультурного виховання у початковій школі $\epsilon$ ті, які побудовані на інтеракціях, іграх, формують комунікативні навички. Це, насамперед, бесіди, діалоги/обговорення, руханки, рольові ігри/інсценування, аналіз історій, малювання з обговоренням, переконування і т. п.

Приміром, руханки не лише дають заряд енергії на початку дня, знімають втому після інтенсивної праці, полегшують перехід до іншого виду діяльності, але й мотивують групову взаємодію, забезпечують психологічну розрядку, що є дуже важливим для досягнення цілей полікультурного виховання. Натомість, рольові ігри/ інсценування дають учням можливість розподіляти ролі і діяти за сценарієм, ефективно апробувати різні моделі поведінки «під маскою», відпрацювати необхідні навички. Аналіз історій передбачає використання реальних і вигаданих історій, міфів, легенд, притч, казок та віршів і $\epsilon$ ефективним для досягнення бажаних змін на рівні ставлень, переконань, усвідомлення і переоцінки цінностей в дітей. Малювання в контексті полікультурного виховання передбачає завдання дітям намалювати і написати щось на конкретну тему. Наприклад, намалювати дитину іншої національності, статі, віри і описати їі історію так, щоб дитину зрозуміли інші.

У підлітковому віц̧і в дитини формується відчуття власної соціальної ідентичності, приналежності до певної соціальної групи, тому доцільним вважаємо проведення різноманітних форм роботи, які дають підліткові зрозуміти, що особистість кожної окремої людини складається з безлічі різних ролей, які вона виконує в житті. Для цього педагогові варто використовувати такі активні й інтерактивні методи полікультурного виховання, що акцентують увагу на схожості й відмінностях носіїв різних культур. Як результат, у підлітків формується позитивна установка й толерантне ставлення до оточуючих; наявність позитивної мотивації до взаємодії з іншою людиною незалежно від іiї культурної ідентичності, повага до людської гідності, здатність до співпереживання, співчуття; вміння критично аналізувати свої дії у середовищі міжкультурної комунікації.

Найбільш ефективними активними й інтерактивними методами полікультурного виховання 3 підлітками слід визнати діалог, дискусію, роботу в парах і групах, мозковий штурм, рольові ігри, контент-аналіз текстів та інших джерел культурної інформації, інтерв'ювання, опитування, метод моделювання конкретних ситуацій, метод кейсів, «криголами», обговорення в колі, виготовлення флаєрів, континуум, оцінку й самооцінку й т. п.

Метод «криголами» передбачає використання вправ для поліпшення психологічного клімату в групі, підвищення самооцінки, розвитку емпатії підлітків. Обговорення в колі забезпечує кожному учаснику висловитися з певної проблеми. Варіаціями цього методу $\epsilon$ метод трикутника/діаманта/концентричних кіл: невеликі групи отримують по 6-9 або більше карток, на яких записують певні навички чи якості (наприклад ті, що демонструють толерантність). Потім учасники розкладають картки у вигляді трикутника, діаманта чи концентричних кіл відповідно до їх значення. Формуються вміння виокремлювати головне i досягати консенсусу. Виготовлення постерів/флаєрів забезпечує розвиток креативності, навичок адвокації, вміння 
працювати в групі. Метод кейсів (конкретних ситуацій) передбачає поділ класу на групи, яким пропонується опис ситуації, заснований на реальних або вигаданих фактах. Групи повинні iі детально проаналізувати й виробити рішення. Виробляється вміння приймати групове рішення проблем, які ілюструють практичну дію різноманітних підходів і концепцій. Метод кейсів передбачає осмислення реальної ситуації полікультурного спілкування й актуалізує комплекс знань, який необхідно засвоїти під час розв'язання певної проблеми. Важливим етапом у такій роботи $є$ рефлексія, під час якої підлітки обговорюють певні особливості, характеристики, яким вони надавали перевагу в процесі роботи над вправою, а також причини такого вибору.

У віці старшокласників як особливої соціальної й вікової групи, як важливого стратегічного ресурсу суспільного розвитку, надзвичайно важливим $є$ досвід міжкультурної взаємодії, що допомагає ефективній соціалізації особистості. У цьому віці характерними є: установки на самовизначення, свідому побудову власного життя, професійна орієнтація, готовність до виконання громадянського обов'язку. Власне, в старшому шкільному віці можна спостерігати перші результати полікультурного виховання, здійсненого у попередні вікові періоди. Тому цей період - це період закріплення отриманих полікультурних знань, умінь і навичок, іноді корекції сформованого рівня полікультурної компетентності. У віці старшокласника остаточно формується світогляд кожного учня/учениці, система переконань, переживань, формується почуття справедливості; відбувається закріплення ототожнення себе з певною соціокультурною спільнотою, етнічною групою, релігійною громадою тощо.

Зі старшокласниками, на нашу думку, найбільш ефективними активними й інтерактивними методами полікультурного виховання є: дебати, метод проєктів, кооперативне навчання, складання культурологічної автобіографії, рольові та ділові ігри, проведення «круглих столів», етнографічні дослідження, кроскультурні моделювання й т. ін.

Так, дебати дають можливість захищати протилежні погляди, розвивати уміння відстоювати свою позицію з повагою до опонента. Метод проєктів спрямований на розвиток пізнавальних навичок старшокласників, умінь самостійно конструювати свої знання, орієнтуватися в інформаційному просторі, розвивати критичне мислення. Результатом розроблення теоретичного проєкту $\epsilon$ презентація способів вирішення проблеми, що вивчається, а практичного конкретний проєкт, готовий для впровадження.

Метод кооперативного навчання (співробітництво учнів у групах) $\epsilon$ надзвичайно важливим, оскільки спільно працювати з людьми різного походження, різних культур - це частина навчання життя в соціумі. Дослідники (Е. Коен, П. Кендзьор) стверджують, що учні, коли перебувають у неоднорідних групах, опановують нові знання значно легше, а це стає поштовхом до обміну думками, що робить учасників дискусії більш відкритими й ближчими один до одного. Кооперативне навчання позитивно впливає на соціальну ідентичність учня. У групі, що складається з членів, які мають різне походження, саме особисті навики й знання школярів стають критеріями інтеграції, а не етнічна чи релігійна приналежність. Відповідно, спільну ідентичність можна розвинути, досягаючи спільних цілей, сприяючи інтеграції учнів у суспільні одиниці, що виходять за межі їхньої специфічної приналежності (Кендзьор, 2016). Приміром, метод кооперативного навчання передбачає розповідь старшокласника про своє життя, а діяльність інших полягає в схематичному зображенні впливів різних культур на життя оповідача. 
Своєю чергою, метод складання культурологічної автобіографії передбачає письмовий опис свого культурного спадку, за допомогою чого учні можуть скласти генеалогічне дерево своєї родини. Метод етнографічних досліджень - це ціннісна практика полікультурної підготовки учнів, що охоплює різні способи ознайомлення 3 культурами - домашні візити, спілкування 3 представниками громади, батьками й учителями учнів; спостереження за поведінкою дітей, інтерв'ювання, участь у житті громади (святах), спілкування з однокласниками іноземного походження. Натомість, метод крос-культурних моделювань вимагає інсценізації ситуацій полікультурного спілкування, сприяє самоаналізу й саморефлексії, завдяки чому учні мають можливість осмислити свою етнічну приналежність, усвідомити себе носіями певної культури.

Таким чином, активні й інтерактивні методи полікультурного виховання дають змогу не лише розвивати мислення учнів й залучати їх до вирішення проблем, максимально наближених до реальних життєвих ситуацій, але й розвивають практичні навички та вміння, сприяють активізації освітньо-виховного процесу, спонукають учнів до творчої участі в ньому і забезпечують розвиток і саморозвиток особистості учня на основі врахування його вікових особливостей, при цьому сприяють розвитку вміння рефлексувати, що дає можливість відкоригувати методику полікультурного виховання 3 метою підвищення його ефективності в конкретному закладі освіти.

Висновки і перспективи подальших розвідок. Отже, активні й інтерактивні методи полікультурного виховання належать до інноваційних i $\epsilon$ умовою для самореалізації особистості учнів в освітньо-виховній діяльності. Використання активних й інтерактивних методів в полікультурному вихованні дає змогу досягти поставлених завдань і сприяє особистісному зростанню як учнів, так і педагогів; сприяє продуктивній й ефективній педагогічній взаємодії в класі, де навчаються учні різних національностей, представники різних культур.

Важливим $є$ розуміння того, що схарактеризовані активні й інтерактивні методи полікультурного виховання необхідно використовувати із урахуванням контексту, характеру міжкультурної взаємодії, особливостей відповідного виховного середовища, від вікових та індивідуально-психологічних особливостей учнів.

Перспективу подальших розвідок у цьому контексті вбачаємо у визначенні змісту полікультурної підготовки вчителів залежно від закладу вищої освіти, визначених цілей, його місцезнаходження, культурною різноманітністю студентів, позаяк полікультурність - важлива складова людського досвіду, через який майбутні особистість навчається жити і працювати в полікультурному середовищі.

\section{СПИСОК ВИКОРИСТАНИХ ДЖЕРЕЛ}

Бойченко, В. (2006). Полікультурне виховання молодших школярів у навчальновиховному процесі школи. Кандидат педагогічних наук. Херсонський державний університет. 22 с.

Кендзьор, П. (2016). Інтеграція через діалог. Система організації полікультурного виховання в школі. Львів: Видавничий Дім «Панорама». 378 с.

Свиридюк, О. (2015). Ключові поняття полікультурного виховання. Збірник наукових праць студентів та молодих учених. Умань: ВПЦ «Візаві», с. 196-200.

Солодка, А. (2005). Полікультурне виховання старшокласників у процесі вивчення гуманітарних предметів. Кандидат педагогічних наук. Інститут проблем виховання. Київ. 15 с.

Петренко, О. (2015). Інноватика у вихованні: засадничі положення. Інноватика у вихованні : зб. наук. пр. Вип. 1. Рівне : РДГУ, с.38-48. 
Дичківська, I. (2004). Інноваційні педагогічні технології: [навч. посіб.]. Київ: Академвидав, $320 \mathrm{c}$.

Кларин, М. (2000). Интерактивное обучение - инструмент освоения нового опыта. Педагогика. № 7, с. 12-18.

Панфилова, А. (2009). Инновачионные педагогические технологии: Активное обучение: учебное пособие. Москва: Академия. $192 \mathrm{c.}$

Пометун, О. та Пироженко, Л. (2004). Сучасний урок. Інтерактивні технологіï навчання. Київ: Видавництво А.С.К. 192 с.

\section{REFERENCES}

Boichenko, V. (2006). Polikulturne vykhovannia molodshykh shkoliariv u navchalno-vykhovnomu protsesi shkoly [Multicultural Education of Elementary Schoolchildren in the Educational Process of School]. Kandydat pedahohichnykh nauk. Khersonskyi derzhavnyi universytet. 22 s. (in Ukrainian)

Kendzor, P. (2016). Intehratsiia cherez dialoh. Systema orhanizatsii polikulturnoho vykhovannia $v$ shkoli [Integration through Dialogue. The System of Organization of Multicultural Education at School]. Lviv: Vydavnychyi Dim "Panorama". 378 s. (in Ukrainian)

Svyrydiuk, O. (2015). Kliuchovi poniattia polikulturnoho vykhovannia [Key Concepts of Multicultural Education]. Zbirnyk naukovykh prats studentiv ta molodykh uchenykh. Uman: VPTs "Vizavi”, s. 196-200. (in Ukrainian)

Solodka, A. (2005). Polikulturne vykhovannia starshoklasnykiv u protsesi vyvchennia humanitarnykh predmetiv [Multicultural Education of High School Students in the Process of Studying Humanities]. Kandydat pedahohichnykh nauk. Instytut problem vykhovannia. Kyiv. 15 s. (in Ukrainian)

Petrenko, O. (2015). Innovatyka u vykhovanni: zasadnychi polozhennia [Innovation in Education: Basic Principles]. Innovatyka u vykhovanni : zb. nauk. pr. Vyp. 1. Rivne : RDHU, s.38-48. (in Ukrainian)

Dychkivska, I. (2004). Innovatsiini pedahohichni tekhnolohii [Innovative Pedagogical Technologies]: [navch. posib.]. Kyiv: Akademvydav, 320 s. (in Ukrainian)

Klarin, M. (2000). Interaktivnoe obuchenie - instrument osvoeniya novogo opyta [Interactive Learning as a Means for Developing New Experiences]. Pedagogika. No 7, s. 12-18. (in Russian)

Panfilova, A. (2009). Innovatsionnye pedagogicheskie tekhnologii: Aktivnoe obuchenie: uchebnoe posobie [Innovative Pedagogical Technologies: Active learning: manual book]. Moskva: Akademiya. 192 s. (in Russian)

Pometun, O. ta Pyrozhenko, L. (2004). Suchasnyi urok. Interaktyvni tekhnolohii navchannia [Modern Lesson. Interactive Learning Technologies]. Kyiv: Vydavnytstvo A.S.K. 192 s. (in Ukrainian) 
Інноватика у вихованні. Випуск 11. Том 1. 2020.

\title{
ACTIVE AND INTERACTIVE METHODS OF MULTICULTURAL EDUCATION OF STUDENTS OF DIFFERENT AGE GROUPS
}

\author{
Oksana Petrenko \\ Doctor of Sciences (in Pedagogy), \\ Professor, Head at the Department of Theory and Methods of Education, \\ Rivne State University for the Humanities, \\ Rivne, Ukraine \\ ORCID: 0000-0001-6906-3542, \\ e-mail: o.b.petrenko@gmail.com
}

\begin{abstract}
Multicultural education is considered as a process of purposeful socialization of students, that involves mastering the system of national and universal cultural values, communicative and general cultural empathic skills, giving students the opportunity to intercultural interaction and show understanding of other cultures, as well as tolerance towards their carriers.

The expediency of using teachers in the process of multicultural education of active and interactive methods that promote effective interaction in the classroom with representatives of different cultures is substantiated. Some active and interactive methods of multicultural education according to the age groups of students have been characterized.

It has been established that the most effective methods of organizing multicultural education at elementary school are those that are based on interaction, games, form communication skills, such as: conversations, dialogues / discussion, outdoor games, role-playing games / dramatization, analysis of stories, drawing with discussion, beliefs etc.

The most effective active and interactive methods of multicultural education with adolescents have been identified, such as: dialogue, discussion, work in pairs and groups, brainstorming, role-playing games, content analysis of texts and other sources of cultural information, interviewing, polling, a method for modeling specific situations, case studies, "icebreakers", discussion in a circle, making flyers, continuum, assessment and self-esteem, etc.

The most effective active and interactive methods of multicultural education of high school students are: debates, project method, cooperative training, compilation of culturological autobiography, role-playing and business games, round tables discussions, ethnographic research, cross-cultural modeling, etc.

It is proved that the use of active and interactive methods in multicultural education allows us to achieve the set goals and promotes the personal growth of students as well as teachers.
\end{abstract}

Keywords: multicultural education, active and interactive methods of multicultural education, students, age groups, tolerance.

Стаття надійшла до редакиії 20. 04. 2020 р. 